\title{
Geochemical characterization of sediment cores from the continental shelf off the western rias area (NW Iberian Peninsula)
}

\section{Caracterización geoquímica de núcleos de sedimento de la plataforma continental en el área de las rías occidentales (NW Península Ibérica)}

\author{
Catarina Corredeira ${ }^{1}$ \\ M. Fátima Araújo ${ }^{1}$ \\ Ângela Gouveia ${ }^{1}$ \\ J.M. Jouanneau ${ }^{2}$ \\ ${ }^{1}$ Instituto Tecnológico e Nuclear, Química \\ Estrada Nacional 10, 2686-953, Sacavém, Portugal \\ *E-mail: catarina@itn.mces.pt \\ ${ }^{2}$ DGO-UMR 5805 CNRS, Université Bordeaux I \\ Av. des Facultés \\ 33405 Talence Cedex, France \\ Recibido en junio de 2003; aceptado en abril de 2004
}

\begin{abstract}
The present work aims to understand the origin of sediments deposited in the Galician coastal zone and continental shelf. Selected sediment cores were studied using different geochemical approaches: grain-size measurements, carbonate determinations and elemental analyses. Chemical analyses were carried out by multielemental techniques: energy dispersive X-ray fluorescence spectrometry (EDXRF) and instrumental neutron activation analysis (INAA). The grain-size distribution demonstrated that samples collected off the rias (Vigo and Pontevedra) contain higher percentages of silt and clay. The carbonate enrichment measured in some sediment samples with different locations and granulometries seems to indicate that the sediments might have distinct origins: biological fluvial productivity in sediments off the rias and marine biogenic activities for the deeper continental shelf sediments. Chemical analyses made it possible to distinguish different elemental sources: lithogenic, anthropogenic and biogenic. The downcore profiles of the elemental composition showed signs of a recent continental contamination for $\mathrm{Zn}$ and to a lesser extent for As, although there are no signs of exportation to the adjacent continental shelf. Other elements that can indicate anthropogenic activities were present in low concentrations compared with reference values. The $\mathrm{Zr}$ distribution determined in sediments collected along a straight line off Vigo Ria increases westwards, indicating an absence of recent exportation of this element from the continent.
\end{abstract}

Key words: sedimentary geochemistry, NW Iberian shelf, energy dispersive X-ray fluorescence spectrometry, instrumental neutron activation analysis, heavy metals.

\section{Resumen}

En el presente trabajo se busca entender el origen de los sedimentos depositados en la zona costera y la plataforma continental de Galicia. Se estudiaron núcleos de sedimentos usando diferentes métodos geoquímicos: medición del tamaño de grano, determinación de carbonato y análisis de elementos. Se realizaron análisis químicos mediante técnicas multielementales: espectrometría de fluorescencia de rayos X por energía dispersiva (EDXRF) y análisis por activación neutrónica instrumental (INAA). La distribución del tamaño de grano mostró que los sedimentos recolectados frente a las rías de Vigo y Pontevedra contenían procentajes mayores de limo y arcilla. El enriquecimiento de carbonato medido en algunas muestras de sedimento de diferentes sitios y su granulometría parecen indicar distintos orígenes de los sedimentos: productividad biológica fluvial para los sedimentos frente a las rías y actividad biogénica marina para los sedimentos de la plataforma continental. Los perfiles de la composición de elementos del núcleo indicaron contaminación continental reciente de $\mathrm{Zn}$ y, en menor grado, de As, aunque sin evidencias de exportación a la plataforma continental adyacente. Otros elementos que pueden indicar actividades antropogénicas se encontraron en concentraciones bajas en comparación con valores de referencia. La distribución de Zr en los sedimentos recolectados a lo largo de una línea recta enfrente de la Ría de Vigo aumenta hacia el oeste, lo que indica que este elemento no ha sido exportado recientemente desde el continente.

Palabras clave: geoquímica sedimentaria, plataforma ibérica noroccidental, espectrometría de fluorescencia de rayos X por energía dispersiva, análisis por activación neutrónica instrumental, metales pesados. 


\section{Introduction}

The northern Portuguese coastal zone is characterized by the presence of large rivers draining highly populated and industrialized regions, with different types of lithologies and levels of anthropogenic influence (Araújo et al., 2002). To the north, on the Galician coast, the influence of several rias drastically changes the coastal morphology. This region is characterized by a large sinuosity and the presence of the western Galician rias: Vigo, Pontevedra, Arosa and Muros.

Two major deposits of fine sediments are located along the northwestern shelf. One extends off the Minho River along the Galician rias and the other is located in the middle shelf, north of the Douro River.

Recent published works (Araújo et al., 2002; Jouanneau et al., 2002; Oliveira et al., 2002) indicated that the main source of the fine sediments in the southern deposit was the Douro River. Geochemical studies carried out in different sets of sediments (Douro Estuary, Douro deposit, Minho Estuary and Galicia deposit), evidenced striking similarities between the Douro estuarine samples and the Douro and Galicia fine sediments deposited at the mid-shelf (Araújo et al., 2002). Nevertheless, the chemical composition of the Minho estuarine sediments demonstrates that the Minho sediment load does not have a major contribution to the Galicia mud field. Besides, other studies carried out in a northern area of the Galicia mud field (Rey-Salgado, 1993) showed that nowadays, there are no inputs of sediment from the north towards the Galician shelf. Thus, the integration of these results may indicate that the main source of the fine sediments deposited at the Galician shelf could be located southwards at the Douro river/deposit (Araújo et al., 2002). However, geochemical studies on the Minho/ Galicia system were based just on a few sediment samples collected from a confined region located to the south of the deposit, in front of the Minho Estuary, at the Portuguese shelf.

In the present work we are extending this studies to the north, to the area between the mouth of the Minho River and the Finisterra Cape in the northwestern Iberian coastal zone and shelf. This study aims to investigate the Minho/Galician shelf sedimentary dynamics based on the geochemical characterization of selected sections of sediment cores collected from the Galician rias area up to the mid-continental shelf. Chemical and grain-size analyses were used to determine the distribution of natural and anthropogenic metals (contaminants) in the region. Selected elements of the data set obtained allowed to infer about the origin of the fine deposited sediments and to assess the interactions between continental and marine sediments.

\section{Materials and methods}

Eleven sediment cores, with lengths ranging from 10 to $235 \mathrm{~cm}$, were collected along the northwestern Iberian shelf (fig. 1) with corers and box-corers (Reineck), during the GAMINEX (June 1998) and Charles Darwin (CD110, December 1997) cruises.

\section{Introducción}

La zona costera del norte de Portugal se caracteriza por la presencia de grandes ríos que drenan regiones altamente pobladas e industrializadas, con diferentes tipos de litologías e influencia antropogénica (Araújo et al., 2002). Al norte, en la costa de Galicia, la influencia de varias rías cambia drásticamente la morfología costera. Esta región se caracteriza por una gran sinuosidad y la presencia de las rías occidentales de Galicia: Vigo, Pontevedra, Arosa y Muros.

A lo largo de la plataforma noroccidental se localizan dos depósitos principales de sedimentos finos. Uno se extiende del Río Miño por las rías de Galicia y el otro se encuentra en la plataforma media, al norte del Río Duero.

Trabajos publicados recientemente (Araújo et al., 2002; Jouanneau et al., 2002; Oliveira et al., 2002) indican que el Río Duero es la principal fuente de sedimentos finos en el depósito del Duero. Los estudios geoquímicos realizados en diferentes conjuntos de sedimentos (depósito y estuario del Río Duero, estuario del Río Miño y depósito de Galicia) mostraron marcadas similitudes entre las muestras estuarinas del Duero y los sedimentos finos del Duero y de Galicia, depositados en la plataforma media (Araújo et al., 2002). No obstante, la composición química de los sedimentos estuarinos del Río Miño muestra que la carga de sedimento del Miño no contribuye mayormente a la planicie lodosa de Galicia. Además, otros estudios realizados en la zona norte de la planicie lodosa de Galicia (Rey-Salgado, 1993) mostraron que hoy en día no hay aportes de sedimento del norte hacia la plataforma de Galicia. Por tanto, la integración de estos resultados puede indicar que la principal fuente de los sedimentos finos depositados en la plataforma de Galicia se localiza hacia el sur, en el río/depósito del Duero (Araújo et al., 2002). Sin embargo, los estudios geoquímicos en el sistema Miño/Galicia se basaron en unas cuantas muestras recolectadas en una región confinada localizada al sur del depósito, enfrente del estuario del Miño, en la plataforma portuguesa.

En el presente trabajo se extiende estos estudios hacia el norte, al área entre la boca del Río Miño y el Cabo de Finisterra en la zona costera noroccidental ibérica y su plataforma continental. El objetivo de este estudio es investigar la dinámica sedimentaria de la plataforma del Miño/Galicia con base en la caracterización geoquímica de secciones selectas de núcleos de sedimento recolectados desde el área de las rías de Galicia hasta la plataforma continental media. Para determinar la distribución de metales naturales y antropogénicos (contaminantes) en la región se utilizaron análisis químicos y de tamaño de grano. Algunos elementos seleccionados del conjunto de datos obtenidos permitieron inferir sobre el origen de los sedimentos finos depositados y evaluar las interacciones entre los sedimentos continentales y marinos.

\section{Materiales y métodos}

Se recolectaron 11 núcleos de sedimento, de 10 a $235 \mathrm{~cm}$ de largo, a lo largo de la plataforma noroccidental ibérica 
Grain-size analysis and carbonate determinations were carried out on all the samples using a laser diffractometer (Malvern Master Sizer) and a Bernard calcimeter, respectively (Gaulot, 1999).

The uppermost levels of each core (approximately the first $25 \mathrm{~cm}$ ) were dried at $60-80^{\circ} \mathrm{C}$, and then ground to obtain a grain-size fraction smaller than $63 \mu \mathrm{m}$. The homogenized ground material was dried at $110^{\circ} \mathrm{C}$ for $24 \mathrm{~h}$. Fractions between 0.2 and $0.3 \mathrm{~g}$ from all samples were weighed into clean polyethylene vials for instrumental neutron activation analysis (INAA). To determine specific elements (e.g., $\mathrm{Cu}$ and $\mathrm{Pb}$ ), selected fragments were also analyzed by energy-dispersive $\mathrm{X}$-ray fluorescence spectrometry (EDXRF). In this case, $2 \mathrm{~g}$ of homogenized ground sediment were mixed with an organic binder and pressed into pellets.

EDXRF measurements (Araújo et al., 2002) were made by using a Kevex EDX-771 Analyst System, with a rotating 16-position sample tray. A computer running the WinXRF/ ToolBox applications software, which commands the X-ray generator, the detection system and the multichannel analyzer, controls the spectrometer. Samples of standard reference materials were prepared to calibrate the spectrometer and to determine the accuracy and precision of the analytical procedure: SRM1646 Estuarine Sediment and SRM 2704 River Sediment from the US National Institute of Standards and Technology (NIST). Accuracy is usually better than 5\% except for the elements that present strong spectral interference (e.g., As and $\mathrm{Pb}$ ). Precision is better than $10 \%$ for most of the elements, the major differences deriving from counting statistics, for low elemental content or peak overlap.

INAA analyses were carried out via irradiation in the core grid of a research reactor. A $\gamma$-ray spectrometer, consisting of a $150 \mathrm{~cm}^{3}$ coaxial Ge detector and a low-energy photon detector (LEPD) connected through Canberra 2020 amplifiers to an Acuspec B (Canberra) multichannel analyzer, was used. The analytical procedure, accuracy and precision values were identical to those described in Gouveia and Prudêncio (2000). The certified values used were those presented in Govindaraju (1994). The accuracy was satisfactory. The error is lower than $5 \%$ for all the chemical elements determined. The precision has an error of (a) $<3 \%$ for $\mathrm{K}$ and $\mathrm{Fe}$; (b) between $3 \%$ and $5 \%$ for $\mathrm{Zn}$, $\mathrm{Hf}$ and Th; (c) between $5 \%$ and $10 \%$ for Sc, Cr, Co, $\mathrm{Rb}$, Cs, Ta and U; and (d) approximately $12 \%$ for Ba and $13 \%$ for Sb.

\section{Results and discussion}

\section{Grain size and carbonate distribution}

The size, collection depth and results of the mean grain-size distribution and carbonate content of the sediment cores sampled are listed in table 1 . The grain-size analysis of the samples indicates that sediments are mainly composed of silt and clay, with the exception of cores collected at the western locations: KIGX 02, KIGX 05 and S300 (table 1, fig. 1). Cores (fig. 1) con nucleadores y nucleadores de caja (Reineck), durante los cruceros GAMINEX (junio de 1998) y Charles Darwin (CD110, diciembre de 1997).

El análisis de tamaño de grano y la determinación de carbonatos se llevaron a cabo en todas las muestras mediante un difractómetro láser (Malvern Master Sizer) y un calcímetro Bernard, respectivamente (Gaulot, 1999).

Los niveles superiores de cada núcleo (aproximadamente los primeros $25 \mathrm{~cm}$ ) fueron secados a $60-80^{\circ} \mathrm{C}$, y luego molidos para obtener una fracción de tamaño de grano menor que $63 \mu \mathrm{m}$. El material molido homogeneizado se secó a $110^{\circ} \mathrm{C}$ durante $24 \mathrm{~h}$. Fracciones entre 0.2 y $0.3 \mathrm{~g}$ de todas las muestras se pesaron e introdujeron en frascos viales de polietileno limpios para análisis por activación neutrónica instrumental (INAA). Para determinar elementos específicos (e.g., $\mathrm{Cu}$ y $\mathrm{Pb}$ ), también se analizaron fragmentos selectos, mediante espectrometría de fluorescencia de rayos $\mathrm{X}$ por energía dispersiva (EDXRF). En este caso, se mezclaron $2 \mathrm{~g}$ de sedimento molido homogeneizado con un ligante orgánico y se comprimieron en pastillas.

Las mediciones de EDXRF (Araújo et al., 2002) se realizaron utilizando un analizador Kevex EDX-771, con bandeja rotatoria para muestras con 16 posiciones. El espectrómetro es controlado mediante una computadora que utiliza el programa WinXRF/ToolBox, y que también controla el generador de rayos $\mathrm{X}$, el sistema de detección y el analizador de multicanales. Para calibrar el espectrómetro y determinar la exactitud y precisión del procedimiento analítico, se prepararon muestras de materiales estándar de referencia: Sedimento Estuarino

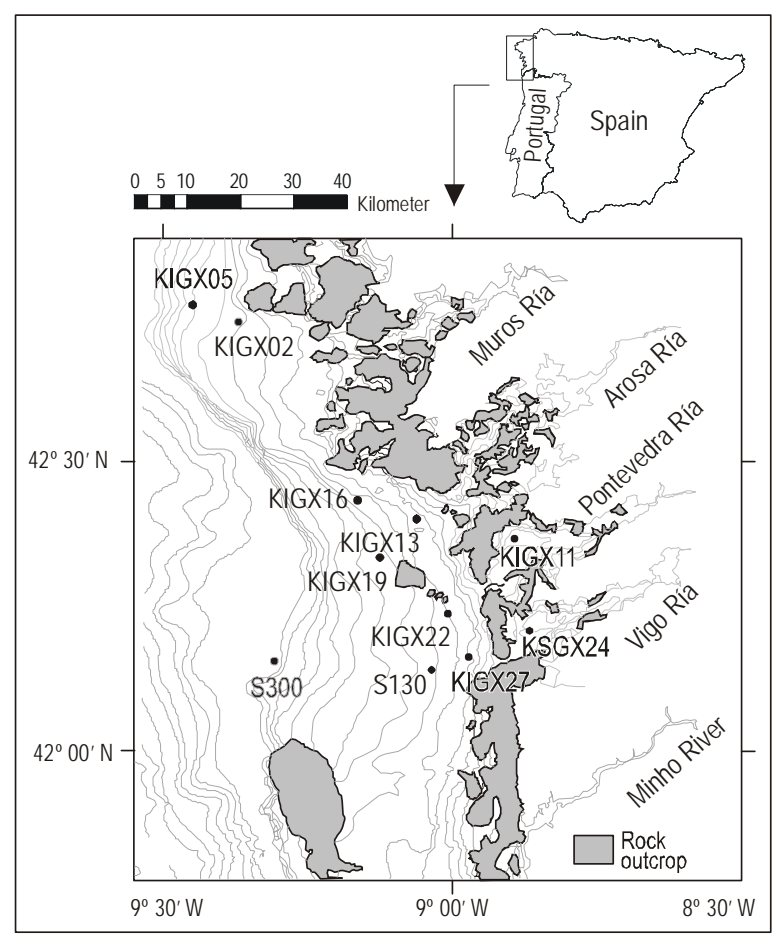

Figure 1. Sediment sampling locations.

Figura 1. Localización de las muestras de sedimento. 
collected at the mouth of the Pontevedra and Vigo rias (KIGX 11 and KSGX 24, at depths of 49 and 39 m, respectively) exhibit high percentages of the silt/clay grain-size fraction. Furthermore, the same cores have the highest carbonate concentration values: KIGX $11=26.1 \%$ and KSGX $24=13.4 \%$. Previously, in studies focused on the northwestern Portuguese shelf (Araújo et al., 2002), the carbonate (or calcium) enrichment had been directly associated with coarse grain-size particles of biogenic origin, particularly in sediments collected at higher depths. Cores collected at the Minho/Galicia shelf (KIGX 05, KIGX 16, S300 and S130), with lower contents of fine sediments, also present high carbonate contents (10$12.8 \%)$. This opposite behaviour might be an indication of the different origin of the two sediment groups. Carbonates in sediments collected at the mouth of the rias are probably the result of high biological productivity, due to upwelling processes that occur in this region (Prego, 1993). In previous studies carried out at the Vigo Ria, the carbonated enriched materials were concentrated near the mouth, falling rapidly into the inner ria and more slowly offshore (Rubio et al., 2000). For the coarser sediments collected at the mid-shelf (between 126 and $213 \mathrm{~m}$ depth), the carbonate enrichment is probably of a marine biogenic origin, similar to that observed in sediments collected farther south.

\section{Elemental distribution}

The minimum and maximum concentration values determined in each core of some lithogenic ( $\mathrm{K}$ and $\mathrm{Zr}$ ) and anthropogenic $(\mathrm{Cu}, \mathrm{Zn}, \mathrm{As}$ and $\mathrm{Pb}$ ) elements are listed in table 2. In general, concentration values for the lithogenic elements are comparable to those published in Salomons and Förstner (1984), except for the case of $\mathrm{Zr}$. The $\mathrm{Zr}$ contents in the shelf sediments are very high (max. $=1176 \mathrm{mg} \mathrm{kg}^{-1}$; reference value $=160 \mathrm{mg} \mathrm{kg}^{-1}$ ), probably because of the presence of

Table 1. Average values of the grain-size and carbonate percentage. Tabla 1. Valores promedio de los porcentajes de tamaño de grano y de carbonato.

\begin{tabular}{lccc}
\hline Core (length) & Depth $(\mathrm{m})$ & $<63 \mu \mathrm{m}(\%)$ & $\mathrm{CaCO}_{3}(\%)$ \\
\hline KIGX 02 $(10 \mathrm{~cm})$ & 127 & 39.9 & 7.8 \\
KIGX 05 $(17 \mathrm{~cm})$ & 141 & 43.6 & 10.0 \\
KIGX $11(27 \mathrm{~cm})$ & 49 & 76.7 & 26.1 \\
KIGX $13(23 \mathrm{~cm})$ & 101 & 53.0 & 7.5 \\
KIGX 16 $(32 \mathrm{~cm})$ & 126 & 67.0 & 12.6 \\
KIGX $19(16 \mathrm{~cm})$ & 133 & 53.6 & 3.6 \\
KIGX 22 $(38 \mathrm{~cm})$ & 113 & 84.6 & 4.5 \\
KIGX 27 $(19 \mathrm{~cm})$ & 99 & 73.1 & 6.3 \\
KSGX $24(235 \mathrm{~cm})$ & 39 & 84.3 & 13.4 \\
S300 $(30 \mathrm{~cm})$ & 213 & 40.2 & 12.8 \\
S130 $(23 \mathrm{~cm})$ & 132 & 60.0 & 11.1 \\
\hline
\end{tabular}

SRM1646 y Sedimento de Río SRM 2704 del Instituto Nacional de Estándares y Tecnología (NIST) de los Estados Unidos. La exactitud suele ser mejor que 5\% excepto para los elementos que presentan interferencia espectral fuerte (e.g., As y $\mathrm{Pb}$ ). La precisión es mejor que $10 \%$ para la mayoría de los elementos, derivando las principales diferencias de las estadísticas de conteo del bajo contenido o el traslapo de contenidos máximos.

Los análisis de INAA se llevaron a cabo por irradiación en la rejilla del núcleo de un reactor de investigación. Se utilizó un espectrómetro de rayos $\gamma$, que consiste de un detector coaxial de Ge de $150 \mathrm{~cm}^{3}$ y un detector fotónico de baja energía (LEPD) conectados mediante amplificadores marca Canberra (modelo 2020) a un analizador multicanal Acuspec B (Canberra). El procedimiento analítico y los valores de exactitud y precisión fueron idénticos a los descritos en Gouveia y Prudêncio (2000). Los valores certificados utilizados fueron los reportados por Govindaraju (1994). La exactitud fue satisfactoria. El error es menor que 5\% para todos los elementos químicos determinados. La precisión tiene un error de (a) $<3 \%$ para K y Fe; (b) entre 3\% y 5\% para Zn, Hf y Th; (c) entre 5\% y $10 \%$ para Sc, Cr, Co, Rb, Cs, Ta y U; y (d) aproximadamente $12 \%$ para Ba y $13 \%$ para Sb.

\section{Resultados y discusión}

\section{Tamaño de grano y distribución de carbonatos}

En la tabla 1 se presentan el tamaño, la profundidad de recolección y los resultados de la distribución del tamaño de grano medio y el contenido de carbonato de los núcleos de sedimentos muestreados. El análisis del tamaño de grano de las muestras indica que los sedimentos están compuestos principalmente de limo y arcilla, con excepción de los núcleos recolectados en las localidades occidentales: KIGX 02, KIGX 05 y S300 (tabla 1, fig. 1). Los núcleos recolectados en la boca de las rías de Pontevedra y Vigo (KIGX 11 y KSGX 24, a 49 y $39 \mathrm{~m}$ de profundidad, respectivamente) tienen procentajes altos de la fracción de grano limo/arcilla. Asimismo, estos mismos núcleos tienen los valores más altos de concentración de carbonatos: KIGX $11=26.1 \%$ y KSGX $24=13.4 \%$. Previamente, en estudios sobre la plataforma noroccidental protuguesa (Araújo et al., 2002), se había asociado el enriquecimiento en carbonato (o calcio) directamente con las partículas de grano grueso de origen biogénico, particularmente en los sedimentos recolectados a mayores profundidades. Los núcleos recolectados de la plataforma de Miño/Galicia (KIGX 05, KIGX 16, S300 y S130), con menores contenidos de sedimentos finos, también muestran altos contenidos de carbonato (10-12.8\%). Este comportamiento opuesto puede ser indicativo del diferente origen de ambos grupos de sedimento. Los carbonatos en los sedimentos recolectados en la boca de las rías probablemente se deben a la alta productividad biológica causada por los procesos de surgencia que se presentan en esta región (Prego, 1993). En otros estudios realizados en la Ría de Vigo, 
heavy minerals like zircon, frequently accumulated in the coarser grain-size fractions. At the Portuguese shelf, coarse sediments enriched in $\mathrm{Zr}$ are usually located in confined areas and concentrated in the coastal zone, indicating in this case, a continental contribution and a mineral fractionation by faster settling (Araújo et al. 2002). In the present study, the Zr spatial distribution along a straight line on the continental shelf off the Vigo Ria, shows a consistent increase in the $\mathrm{Zr}$ concentration westwards, directly correlated $\left(R^{2}=0.80\right)$ with the grain size (fig. 2). This behaviour suggests that sediments have not been exported from the Vigo Ria recently. The origin and distribution of zircon minerals along the Iberian shelf has been a subject of discussion in the past. In a comprehensive study on the sedimentary dynamics of the Portuguese shelf, Dias (1987) attributed the zircon distribution to relict sediments, disseminated along the northern Portuguese shelf. Also, according to Cascalho and Carvalho (1993), defined areas of zirconenriched sediments are widely spread along the northern shelf.

The spatial distribution of the elements that may have anthropogenic origin indicates enrichment in $\mathrm{Zn}$, and to a lesser extent in $\mathrm{As}$ and $\mathrm{Pb}$, exclusively for the sediments collected at the mouth of the rias. Particularly, sediments at the mouth of the Vigo Ria present higher concentrations values for Zn, reaching $225 \mathrm{mg} \mathrm{kg}^{-1}$ (KSGX 24) in the surface layers of the core. This result indicates a recent anthropogenic contamination in the region, probably as a result of urban wastes and industrial effluents because of the presence of naval construction works and several industries settled in a highlypopulated region. Geochemical studies (Prego and CobeloGarcía, 2003) of sediments collected along the rias have also reported heavy metal contamination. Sediment composition los materiales enriquecidos con carbonato se concentraron cerca de la boca, decreciendo rápidamente hacia la parte interior de la ría y más lentamente mar adentro (Rubio et al., 2000). El enriquecimiento en carbonato en los sedimentos más gruesos recolectados en la plataforma media (entre 126 y $213 \mathrm{~m}$ de profundidad) probablemente sea de origen biogénico marino, similar a lo observado en los sedimentos recolectados más al sur.

\section{Distribución de los elementos}

En la tabla 2 se presentan las concentraciones mínima y máxima determinadas en cada núcleo de algunos elementos litogénicos (K y Zr) y antropogénicos (Cu, Zn, As y $\mathrm{Pb})$. En general, los valores para los elementos litogénicos son comparables con los publicados por Salomons y Förstner (1984), excepto en el caso de $\mathrm{Zr}$. Los contenidos de $\mathrm{Zr}$ en los sedimentos de la plataforma son muy altos (máx. $=1176 \mathrm{mg} \mathrm{kg}^{-1}$; valor de referencia $=160 \mathrm{mg} \mathrm{kg}^{-1}$ ), probablemente por la presencia de minerales pesados como circón, frecuentemente acumulado en las fracciones de grano grueso. En la plataforma portuguesa normalmente se localizan sedimentos gruesos enriquecidos en $\mathrm{Zr}$ en áreas confinadas concentradas en la zona costera, indicando en este caso, una contribución continental y un fraccionamiento de minerales por velocidad de asentamiento (Araújo et al., 2002). En el presente estudio, la distribución espacial de $\mathrm{Zr}$ a lo largo de una línea recta en la plataforma continental frente a la Ría de Vigo, muestra un aumento consistente en la concentración de $\mathrm{Zr}$ hacia el oeste, correlacionado directamente $\left(R^{2}=0.80\right)$ con el tamaño de grano (fig. 2). Este comportamiento sugiere que no se han exportado sedimentos de la Ría de Vigo recientemente. El origen y la distribución de

Table 2. Minimum and maximum elemental concentrations of the sediment cores collected from the continental shelf off the western rias area.

Tabla 2. Concentraciones mínimas y máximas de elementos en los núcleos de sedimento recolectados de la plataforma continental frente a las rías occidentales.

\begin{tabular}{|c|c|c|c|c|c|c|}
\hline & K (\%) & $\mathrm{Cu}\left(\mathrm{mg} \mathrm{kg}^{-1}\right)$ & $\mathrm{Zn}\left(\mathrm{mg} \mathrm{kg}{ }^{-1}\right)$ & As $\left(\mathrm{mg} \mathrm{kg}^{-1}\right)$ & $\mathrm{Zr}\left(\mathrm{mg} \mathrm{kg}^{-1}\right)$ & $\mathrm{Pb}\left(\mathrm{mg} \mathrm{kg}^{-1}\right)$ \\
\hline & $\min -\max$ & $\min -\max$ & $\min -\max$ & $\min -\max$ & $\min -\max$ & $\min -\max$ \\
\hline KIGX 02 & $2.0-2.3$ & $10-11$ & $67-76$ & $10-14$ & $569-997$ & $9-13$ \\
\hline KIGX 05 & $2.0-2.3$ & $9-13$ & $64-69$ & $12-15$ & $469-568$ & $7-12$ \\
\hline KIGX 16 & $2.0-2.5$ & $8-15$ & $58-87$ & $16-20$ & $384-604$ & $8-16$ \\
\hline KIGX 19 & $2.1-2.6$ & n.d. - n.d. & $83-100$ & $14-23$ & $326-1176$ & n.d. - n.d. \\
\hline KIGX 13 & $2.0-2.1$ & n.d. - n.d. & $68-77$ & $12-16$ & $251-377$ & n.d. - n.d. \\
\hline KIGX 11 & $1.4-1.9$ & $17-19$ & $82-142$ & $16-22$ & $122-188$ & $22-24$ \\
\hline KIGX 22 & $2.1-2.6$ & n.d. - n.d. & $81-94$ & $15-23$ & $248-587$ & n.d. - n.d. \\
\hline KSGX 24 & $1.3-2.4$ & $14-19$ & $77-225$ & $12-23$ & $232-278$ & $13-38$ \\
\hline KIGX 27 & $1.6-2.1$ & $16-18$ & $72-91$ & $10-16$ & $271-362$ & $10-25$ \\
\hline S130 & $1.3-1.7$ & $13-17$ & $71-102$ & $10-16$ & $369-442$ & $11-28$ \\
\hline S300 & $1.8-2.1$ & n.d. - n.d. & $47-54$ & $4-7$ & $247-370$ & n.d. - n.d. \\
\hline
\end{tabular}

n.d. = not determined (INAA analysis). 


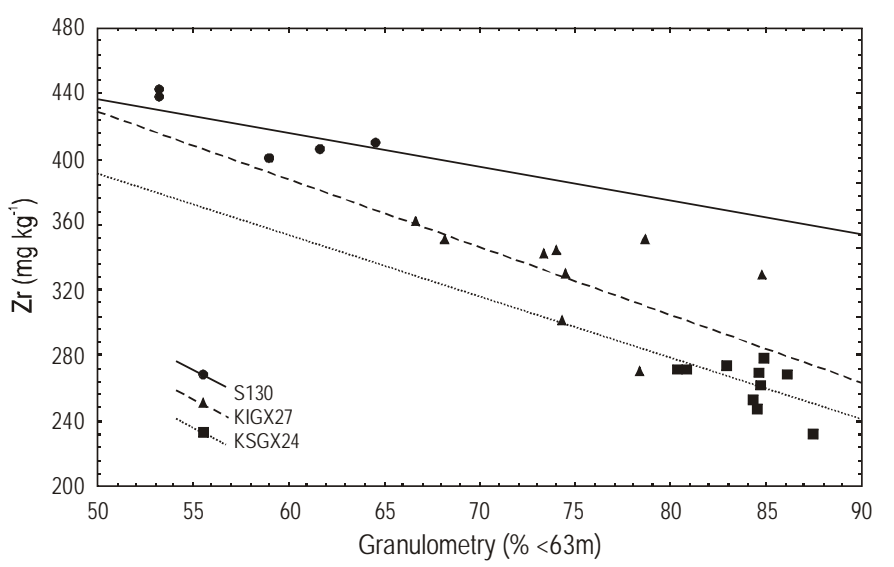

Figure 2. Correlation between the Zr concentration and the granulometry in three sediment cores.

Figura 2. Correlación entre la concentración de Zr y la granulometría en tres núcleos de sedimento.

from similar locations was reported by Vilas et al. (1995, in Prego and Cobelo-García, 2003) as having a maximum value of $201 \mathrm{mg} \mathrm{kg}^{-1}$ for $\mathrm{Zn}$ in the outer area of the Vigo Ria. In the middle of this ria, the heavy industrial activity strongly affects the port zone and a high $\mathrm{Zn}$ contamination was observed $\left(\max .=567 \mathrm{mg} \mathrm{kg}^{-1}\right)$, indicating that the industries are probably the main reason for the high $\mathrm{Zn}$ concentration values observed at the mouth of the Vigo Ria.

The shelf sediments do not exhibit any contamination in $\mathrm{Cu}, \mathrm{Zn}$, As and $\mathrm{Pb}$ (even those collected in the coastal area adjacent to the Vigo Ria: KIGX 27 and S130), since their concentrations are systematically lower than those reported by Prego and Cobelo-García (2003) as natural reference values for Galician marine sediments. These values suggest the absence of any direct influence of the adjacent continental area on the marine sediments.

In summary, the geochemical characterization of the sediment cores studied indicates that sediments deposited at the northern Iberian shelf have three different sources: lithogenic, anthropogenic and biogenic. The sediments collected at the mouth of the Vigo and Pontevedra rias show distinct geochemical characteristics, namely, high carbonate contents due to the high biological productivity, and heavy metal contamination ( $\mathrm{Zn}$, As and $\mathrm{Pb}$ ) as a consequence of human activities (naval construction works, industries and urban wastes). Nevertheless, heavy metal contents in sediments collected at the shelf were within the background values. The gradient of the $\mathrm{Zr}$ and grain-size distributions observed in samples collected at the mouth and off the Vigo Ria, together with the heavy metal distribution on shelf sediments, clearly indicates that the Galician rias do not behave as a sediment source for the continental shelf. In general, the chemical composition (lithogenic and anthropogenic elements) of sediments collected from the midshelf is comparable to the composition determined in sediments collected along the NW Portuguese shelf. minerales de circón en la plataforma ibérica ya ha sido antes tema de discusión. En un estudio sobre la dinámica sedimentaria de la plataforma portuguesa, Dias (1987) atribuyó la distribución de circón a sedimentos relictos diseminados en la plataforma del norte de Portugal. Asimismo, de acuerdo con Cascalho y Carvalho (1993), existen áreas definidas de sedimentos enriquecidos en circón ampliamente distribuidas a lo largo de la plataforma norte.

La distribución espacial de los elementos que pudieran tener un origen antropogénico indica enriquecimiento en Zn y, en menor grado, en $\mathrm{As} \mathrm{y} \mathrm{Pb}$, exclusivamente en los sedimentos recolectados de las bocas de las rías. En particular, los sedimentos de la boca de la Ría de Vigo presentan concentraciones mayores de Zn, alcanzando $225 \mathrm{mg} \mathrm{kg}^{-1}$ (KSGX 24) en los niveles superficiales del núcleo. Este resultado indica una contaminación antropogénica reciente en la región, probablemente como resultado de desechos urbanos y efluentes industriales debidos a la presencia de construcciones navales y varias industrias en esta región altamente poblada. Estudios geoquímicos (Prego y Cobelo-García, 2003) de sedimentos recolectados de las rías también han hecho mención de la contaminación por metales pesados. Según Vilas et al. (1995, en Prego y Cobelo-García, 2003), la composición sedimentaria de localidades similares tiene un valor máximo de $201 \mathrm{mg} \mathrm{kg}^{-1}$ de Zn en la parte exterior de la Ría de Vigo. En el medio de esta ría, la gran actividad industrial afecta fuertemente la zona del puerto, observándose una importante contaminación por Zn (máx. = $567 \mathrm{mg} \mathrm{kg}^{-1}$ ), lo que indica que las industrias probablemente sean la razón principal de las altas concentraciones de este metal en la boca de la Ría de Vigo.

Los sedimentos de la plataforma no muestran contaminación de $\mathrm{Cu}, \mathrm{Zn}$, As y $\mathrm{Pb}$ (ni aun los recolectados en la zona costera adyacente a la Ría de Vigo: KIGX 27 y S130), ya que sus concentraciones son sistemáticamente menores que las reportadas por Prego y Cobelo-García (2003) como valores naturales de referencia para los sedimentos marinos de Galicia. Estos valores sugieren la ausencia de cualquier influencia directa del área continental adyacente sobre los sedimentos marinos.

En conclusión, la caracterización geoquímica de los núcleos de sedimento estudiados indica que los sedimentos depositados en la plataforma ibérica norte tienen tres diferentes fuentes: litógenica, antropogénica y biogénica. Los sedimentos recolectados en la boca de las rías de Vigo y Pontevedra muestran características geoquímicas claras, esto es, altos contenidos de carbonato debidos a la alta productividad biológica y contaminación por metales pesados ( $\mathrm{Zn}$, As y $\mathrm{Pb}$ ) a causa de las actividades humanas (construcción naval, industrias y desechos urbanos). No obstante, los contenidos de metales pesados en los sedimentos recolectados de la plataforma están dentro de los valores de referencia. El gradiente de Zr y las distribuciones del tamaño de grano observados en las muestras recolectadas de la boca y frente a la Ría de Vigo, así como la distribución de metales pesados en los sedimentos de la plataforma indican claramente que las rías de Galicia no se 


\section{Acknowledgements}

The authors thank the scientific teams responsible for the sampling operations developed during the EU OMEX II-II program (MAST3-CT97-0076). This work was partially supported by a FCT (Portugal) research grant to the CRIDA project: Consequences of River Discharge Modifications on Coastal Zone and Continental Shelf (PLE/8/00).

\section{References}

Araújo, M.F., Jouanneau, J.M., Valério, P., Barbosa, T., Gouveia, A., Weber, O., Oliveira, A., Rodrigues, A. and Dias, J.M.A. (2002). Geochemical tracers of northern Portuguese estuarine sediments on the shelf. Prog. Oceanogr., 52(2-4): 277-297.

Cascalho, J. and Carvalho, A.M.G. (1993). Proveniência dos minerais pesados da plataforma continental portuguesa a norte do paralelo de Espinho. Gaia, 6: 10-25.

Dias, J.M.A. (1987). Dinâmica sedimentar e evolução recente da plataforma continental portuguesa setentrional. Ph.D. thesis, Lisbon, $384 \mathrm{pp}$.

Gaulot, S. (1999). La Plateforme Galicienne face aux Rias Bajas: Caractérisation de la couverture sédimentaire et quantification de la sedimentation. Estágio efectuado no DEA "Environnements et Paléoenvironnements Océaniques”. Univ. Bordeaux I, 30 pp.

Gouveia, M.A. and Prudêncio, M.I. (2000). New data on sixteen reference materials obtained by INAA. J. Radioanalyt. Nucl. Chem., 245(1), 105-108.

Govindaraju, K. (1994). Geostandard Newsletter, 8, Spec. Issue.

Jouanneau, J.M., Weber, O., Drago, T., Rodrigues, A., Oliveira, A., Dias, J.A., Garcia, C., Schmidt, S. and Reyss, J.L. (2002). Recent sedimentation and sedimentary budgets on the western Iberian Shelf. Prog. Oceanogr., 52(2-4): 261-275.

Oliveira, A., Rocha, F., Rodrigues, A., Jouanneau, J.M., Dias, A., Weber, O. and Gomes, C. (2002). Clay minerals of the sedimentary cover from the northwestern Iberian shelf. Prog. Oceanogr., 52(2-4), 233-247. comportan como fuentes de sedimento para la plataforma continental. En general, la composición química (elementos litogénicos y antropogénicos) de los sedimentos recolectados de la plataforma media es comparable con la composición determinada en sedimentos recolectados a lo largo de la plataforma noroccidental portuguesa.

\section{Agradecimientos}

Los autores agradecen a los grupos científicos responsables de las operaciones de muestreo desarrolladas durante el programa OMEX II-II (MAST3-CT97-0076) de la UE. Este trabajo fue parcialmente apoyado por una subvención a la investigación de FCT (Portugal) al proyecto CRIDA, Consecias de las Modificaciones de las Descargas Fluviales en la Zona Costera y la Plataforma Continental (PLE/8/00).

Traducido al español por Christine Harris.

Prego, R. (1993). General aspects of carbon geochemistry in the Ria of Vigo, northwestern Spain. Geochim. Cosmochim. Acta, 57: 20412052.

Prego, R. and Cobelo-García, A. (2003). Twentieth century overview of heavy metals in the Galician rias (NW Iberian Península). Environ. Pollut., 121, 425-452.

Rey-Salgado, J. (1993). Relación morfosedimentaria entre la plataforma continental de Galicia y las Rías Bajas y su evolución durante el Cuaternario. Publ. Espec. Inst. Esp. Oceanografia, 17: 233 pp.

Rubio, B., Nombela, M.A. and Vilas, F. (2000). Geochemistry of major and trace elements in sediments of the Ria de Vigo (NW Spain): An assessment of metal pollution. Mar. Pollut. Bull., 40 (11): 968980.

Salomons, W. and Förstner, U. (1984). Metals in the Hydrocycle. Springer-Verlag, 349 pp. 